\title{
Electrocardiogram interpretation in general practice: relevance to prehospital thrombolysis
}

\author{
W A McCrea, S Saltissi
}

\begin{abstract}
Objective-To assess, in the context of their possible role in prehospital thrombolysis, the ability of general practitioners to recognise acute transmural myocardial ischaemia/infarction on an electrocardiogram.

Design-150 doctors (every fifth name) were selected from the alphabetical list of 750 on Merseyside general practitioner register and without prior warning were asked to interpret a series of six 12 lead electrocardiograms. Three of these showed acute transmural ischaemial infarction, one was normal, and two showed non-acute abnormalities. Details of doctors' ages, postgraduate training,
\end{abstract} and clinical practice were sought.

Setting-General practitioners' surgeries and postgraduate centres within the Merseyside area.

Participants-106 general practitioners (mean age 45 years) agreed to participate.

Main outcome measure-Accuracy of general practitioners' interpretations of the six electrocardiograms.

Results $-82 \%$ of general practitioners correctly recognised a normal electrocardiogram. Recognition of acute abnormalities was less reliable. Between 33\% and $61 \%$ correctly identified acute transmural ischaemialinfarction depending on the specific trace presented. Accurate localisation of the site of the infarct was achieved only by between $8 \%$ and $30 \%$ of participants, while between $22 \%$ and $25 \%$ correctly interpreted non-acute abnormalities. Neither routine use of electrocardiography nor postgraduate hospital experience in general medicine was associated with significantly greater expertise.

Conclusion-The current level of proficiency of a sample of general practitioners in the Merseyside area in recognising acute transmural ischaemia/infarction on an electrocardiogram suggests that refresher training is needed if general practitioners are to give prehospital thrombolysis.

Cardiology, Royal

Liverpool Hospital, Liverpool

W A McCrea

S Saltissi

Correspondence to: Dr S Saltissi,

Department of Cardiology, Royal Liverpool Hospital, Liverpool L7 8XP.

Accepted for publication 10 February 1993
It is now generally accepted that in acute myocardial infarction early administration of an intravenous thrombolytic agent is effective in reducing mortality. ${ }^{1-3}$ Furthermore, it has been demonstrated that the earlier thrombolysis is attempted, the greater is the benefit attained. ${ }^{4-6}$

When acute myocardial infarction occurs outside hospital there is a delay between the onset of symptoms and their assessment and treatment by a medical practitioner. ${ }^{78}$ In the United Kingdom patients and their relatives take an average of up to one and a half hours to alert medical and emergency services, ${ }^{8}$ and the median time between the onset of symptoms and admission to a hospital bed is generally four to six hours. ${ }^{8}$ Currently, most medical prehospital coronary care is given by general practitioners. Therefore, if thrombolysis is to be effective, it may well be necessary for this treatment to be initiated outside hospital by the attending family doctor.

Recommendations as to which patients with chest pain should receive thrombolytic agents have varied widely between the different reported studies, some rely on the clinical situation $^{29}$ while most require additional electrocardiographic criteria of infarction. ${ }^{136}$ Thus the ability of general practitioners to interpret accurately electrocardiogram tracings may become increasingly important. However, many general practitioners qualified when there was little emphasis on or testing of electrocardiogram interpretation, and because most general practitioners do not regularly interpret electrocardiograms, ${ }^{1011}$ their skill at interpretation is likely to be underdeveloped.

We report the results of our study of the current ability of a sample of Merseyside general practitioners to detect acute transmural ischaemia/infarction on an electrocardiogram and whether these results indicate that general practitioners require refresher courses in electrocardiogram interpretation.

\section{Methods}

There are approximately 750 general practitioners registered in the Merseyside area. We selected every fifth name in alphabetical order on that register and invited these 150 family doctors to attend one of a series of four clinical meetings held in different parts of the Merseyside region over a 10 day period. All we told these doctors was that these symposia would entail discussions on the role of the general practitioner in early thrombolysis in acute myocardial infarction. Doctors who attended these meetings were requested, without any warning, to interpret a series of six 12 lead electrocardiograms (figs 1-6). 


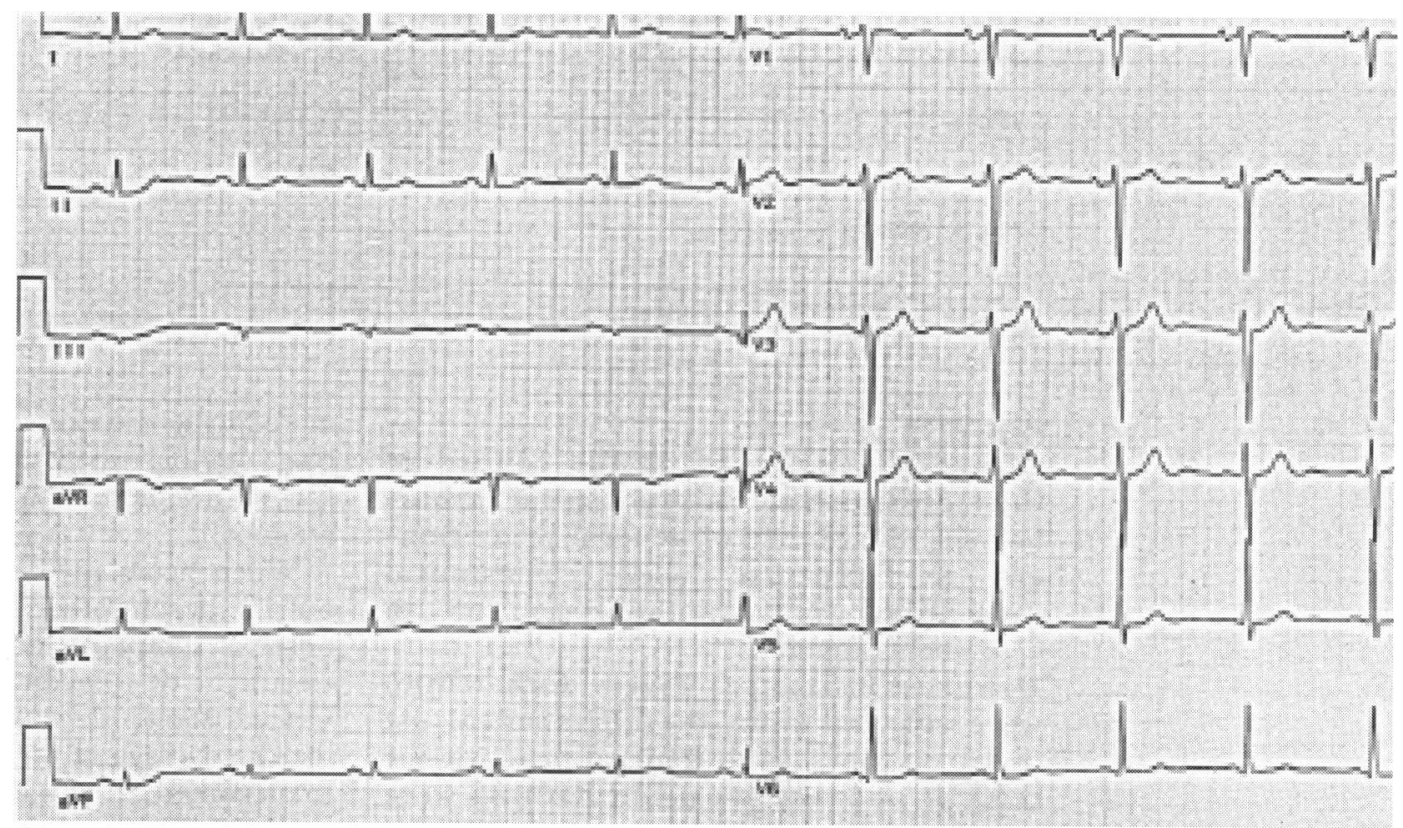

Figure 1 Normal electrocardiogram.

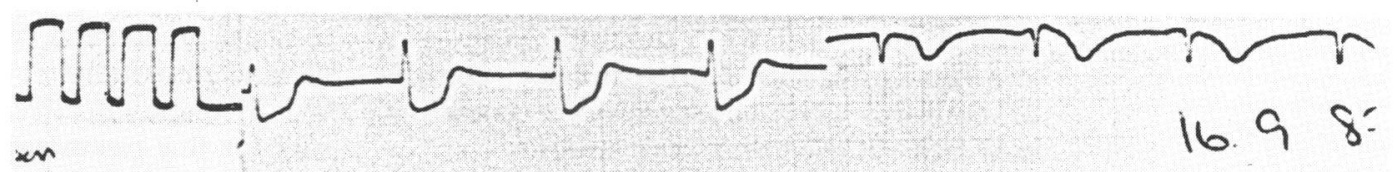
AVL
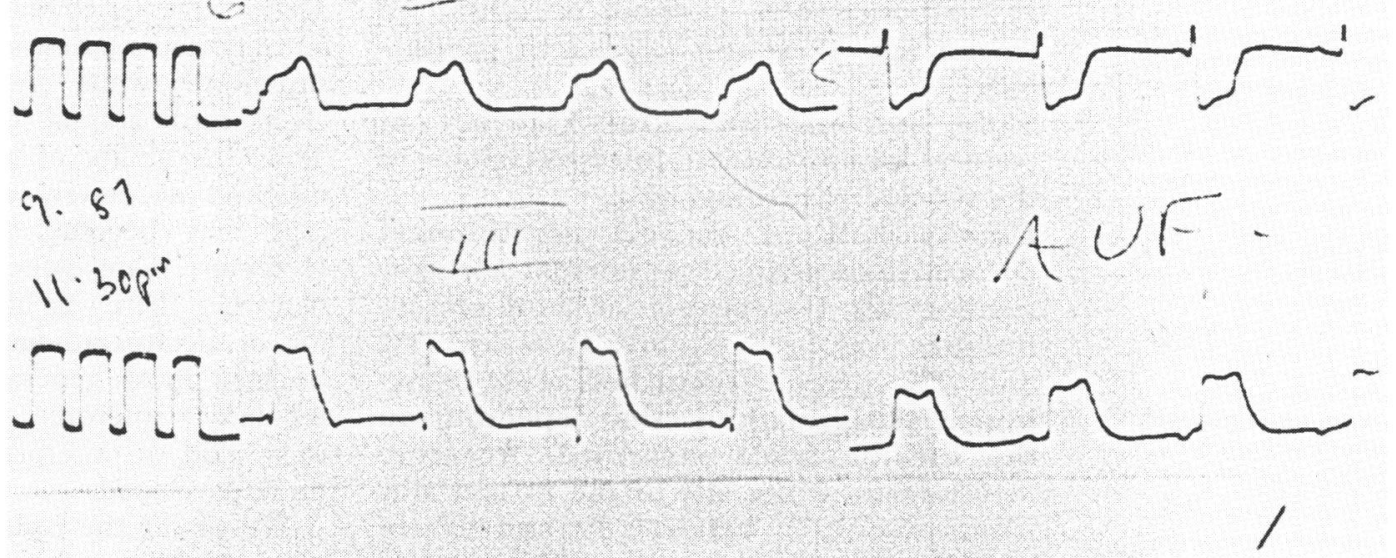

$\cup 4$

U

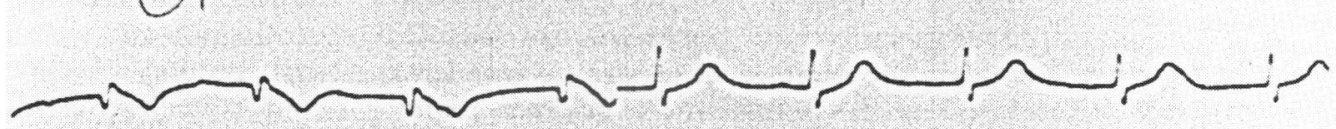

$V_{2}$

US

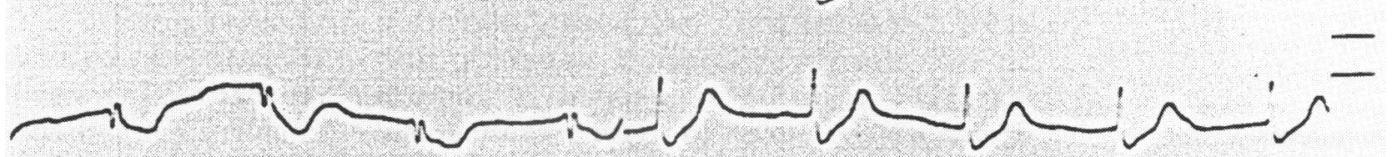

$\sqrt{3}$

16

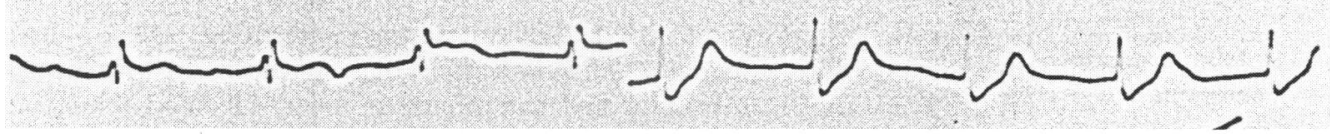

Figure 2 Electrocardiogram demonstrating acute inferior myocardial ischaemialinfarction. 


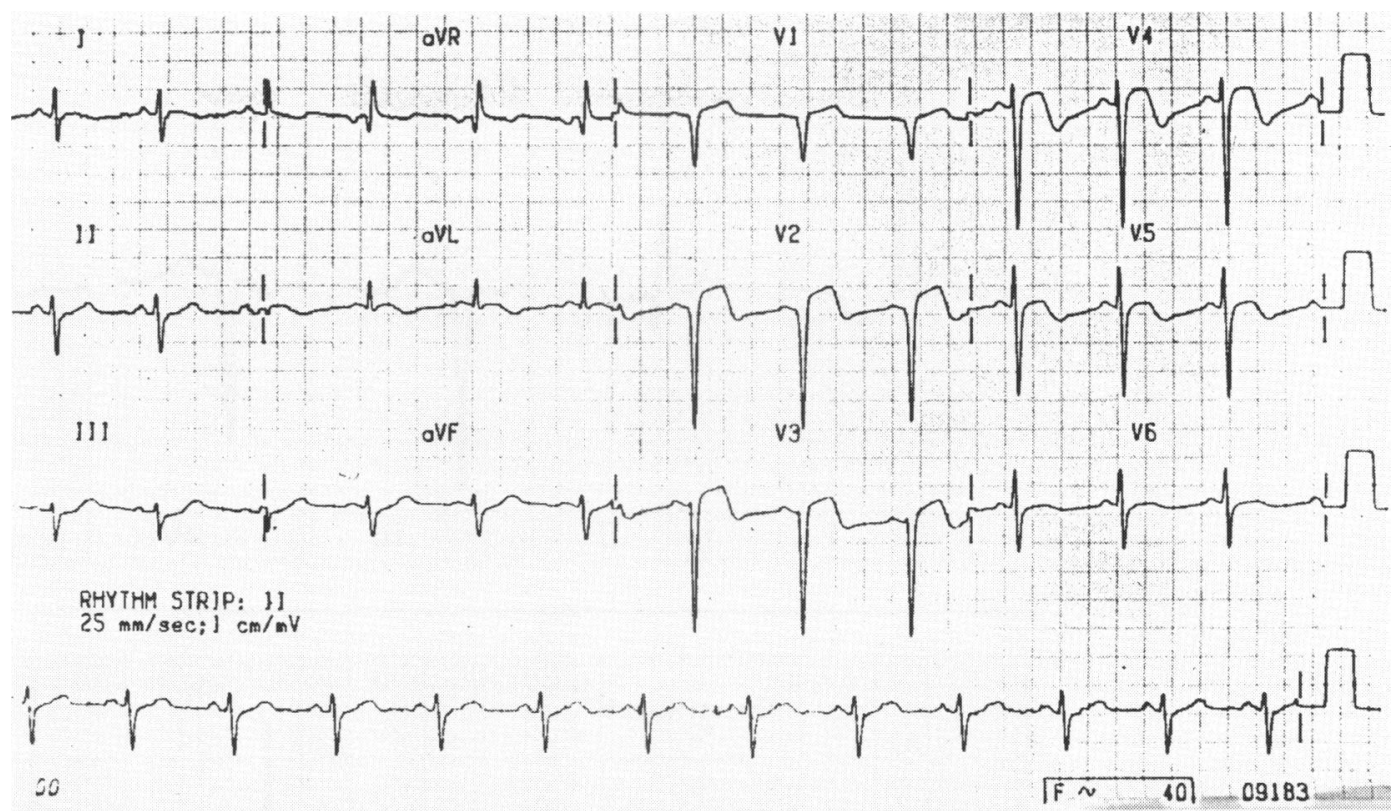

Figure 3 Electrocardiogram demonstrating anteroseptal myocardial ischaemialinfarction.

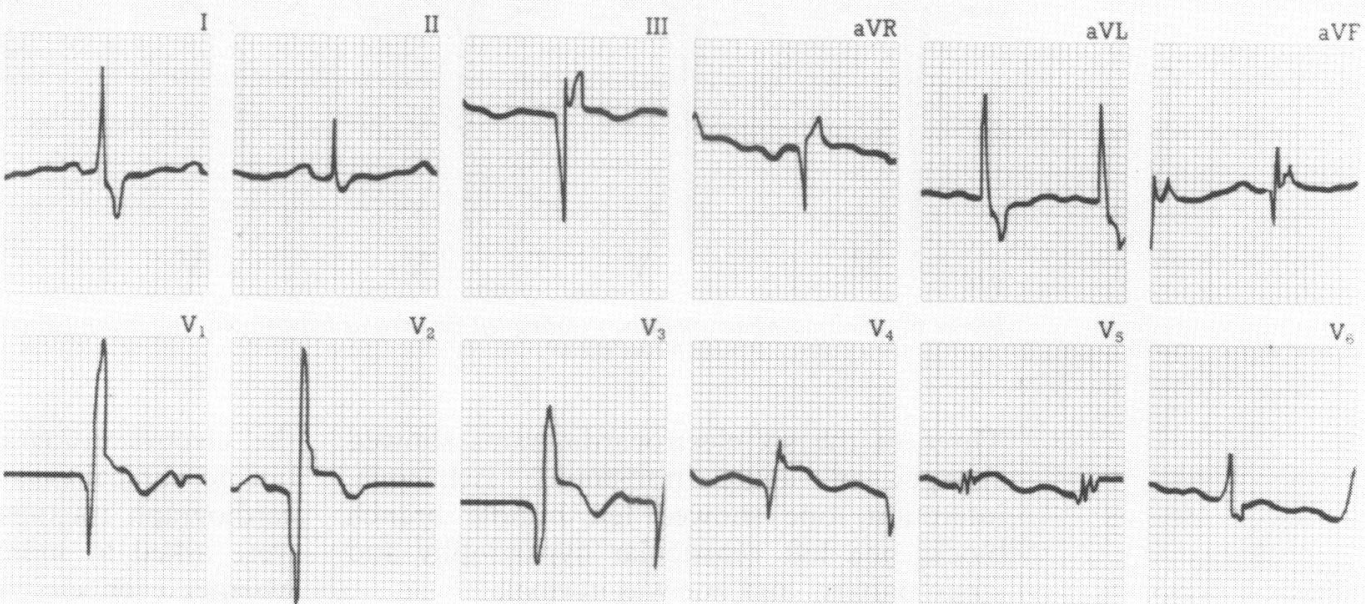

Figure 4 Electrocardiogram demonstrating anterior myocardial ischaemialinfarction with right bundle branch block. (Reprinted with the permission of Dr MC Colquhoun and Syntex Pharmaceuticals Limited.)

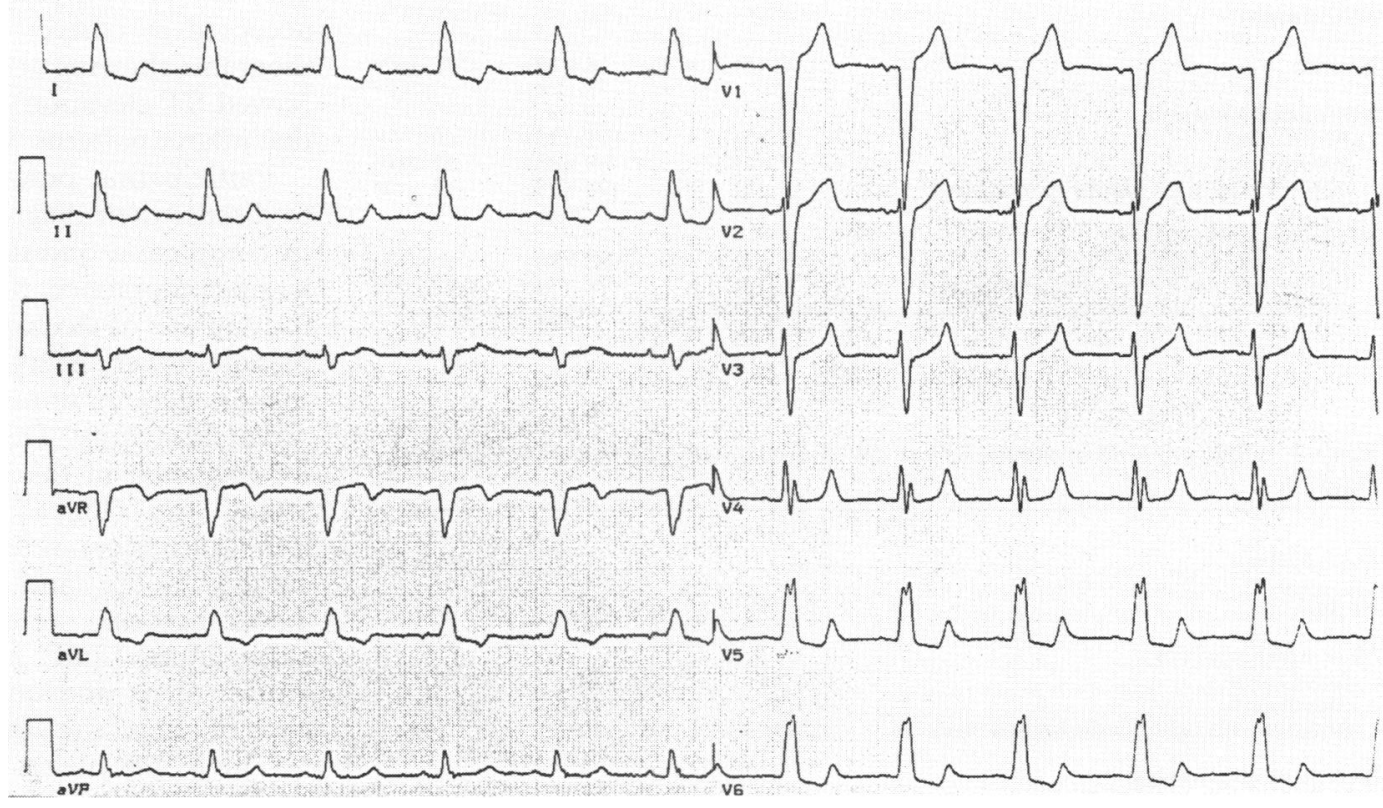

Figure 5 Electrocardiogram demonstrating left bundle branch block. 

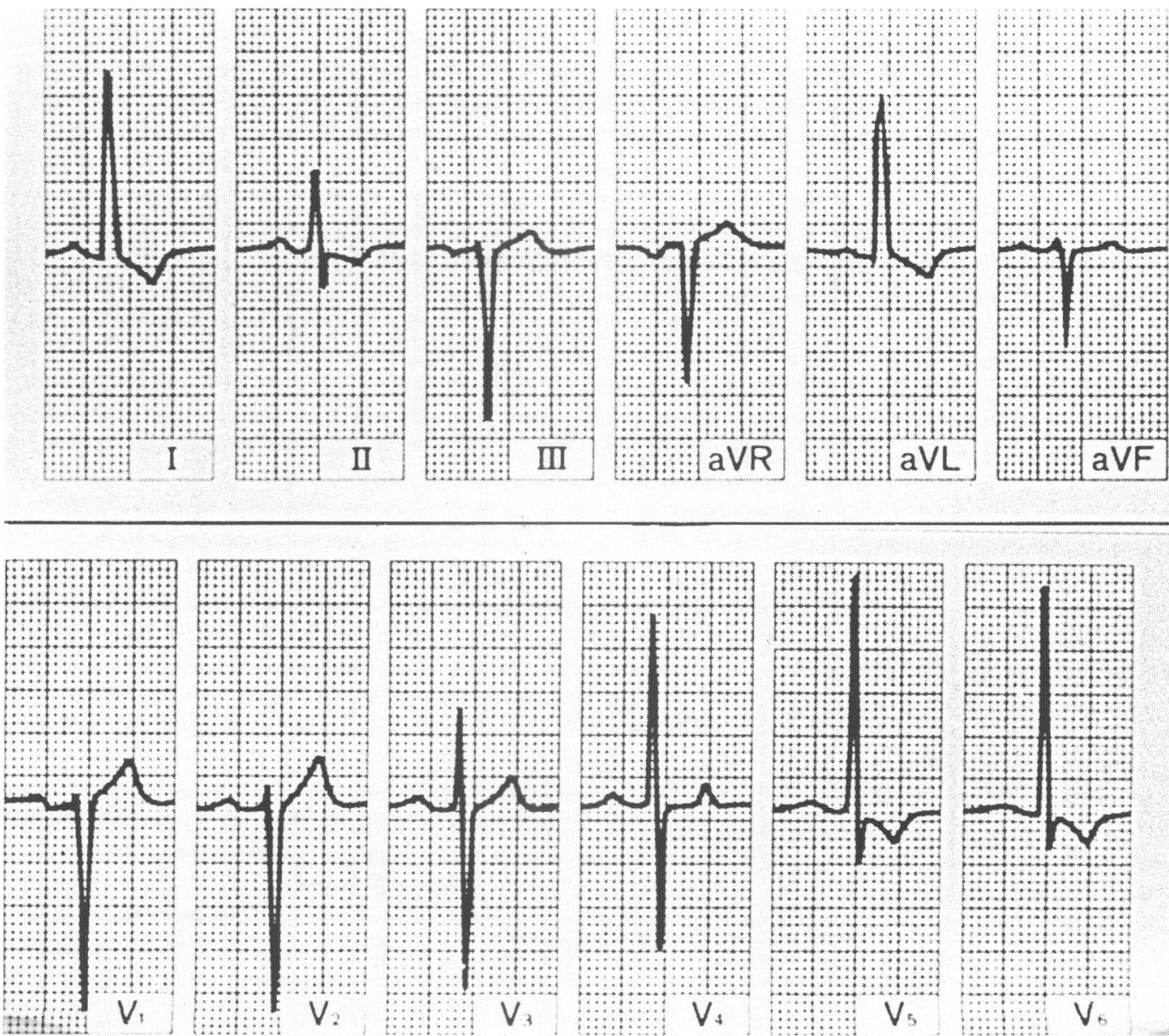

Figure 6 Electrocardiogram demonstrating left ventricular hypertrophy and strain pattern.

Three of the six electrocardiograms showed changes of acute transmural ischaemia/ infarction, one showed left bundle branch block, one left ventricular hypertrophy and strain pattern, and one was normal.

Participants were informed that none of

Table 1 General practitioners' classification of electrocardiograms as either normal or abnormal

\begin{tabular}{llrr}
\hline ECG diagnosis & $\begin{array}{l}\text { Don't know } \\
(\%)\end{array}$ & $\begin{array}{l}\text { Abnormal } \\
(\%)\end{array}$ & $\begin{array}{l}\text { Normal } \\
(\%)\end{array}$ \\
\hline Normal & $5(5)$ & $14(13)$ & $87(82)$ \\
Myocardial infarction: & & & \\
$\quad$ Acute inferior & $5(5)$ & $101(95)$ & 0 \\
$\quad \begin{aligned} \text { Anteroseptal } \\
\text { Anterior with right bundle branch block }\end{aligned}$ & $7(7)$ & $\begin{array}{r}88(83) \\
94(88)\end{array}$ & $\begin{array}{r}11(10) \\
\text { Non-acute abnormality: }\end{array}$ \\
$\quad$ Left bundle branch block & $5(5)$ & $85(80)$ & $16(15)$ \\
$\quad$ Left ventricular hypertrophy and strain & $6(6)$ & $78(74)$ & $22(20)$ \\
\hline
\end{tabular}

Table 2 Ability of general practitioners to detect myocardial infarction and offer correct diagnosis

\begin{tabular}{|c|c|c|c|}
\hline ECG diagnosis & $\begin{array}{l}\text { MI present } \\
(\%)\end{array}$ & $\begin{array}{l}\text { No MI present } \\
(\%)\end{array}$ & $\begin{array}{l}\text { Correct } \\
\text { diagnosis (\%) }\end{array}$ \\
\hline Normal & $1 \quad(1)$ & $100(94)$ & $87(82)$ \\
\hline $\begin{array}{l}\text { Myocardial infarction: } \\
\text { Acute inferior } \\
\text { Anteroseptal } \\
\text { Anterior with right bundle branch block }\end{array}$ & $\begin{array}{l}65(61) \\
48(45) \\
35(33)\end{array}$ & $\begin{array}{ll}36 & (34) \\
51 & (48) \\
63 & (59)\end{array}$ & $\begin{array}{rr}32 & (30) \\
29 & (27) \\
9 & (8)\end{array}$ \\
\hline $\begin{array}{l}\text { Non-acute abnormality: } \\
\text { Left bundle branch block } \\
\text { Left ventricular hypertrophy and strain }\end{array}$ & $\begin{aligned} 4 & (4) \\
10 & (9)\end{aligned}$ & $\begin{array}{l}97(91) \\
90(85)\end{array}$ & $\begin{array}{ll}27 & (25) \\
23 & (22)\end{array}$ \\
\hline
\end{tabular}

the electrocardiograms showed arrhythmias but no clinical details relating to the electrocardiograph tracings were divulged. Doctors were asked to indicate on an answer sheet whether each electrocardiogram was normal or abnormal and if they considered the trace to be abnormal they were encouraged to make a specific diagnosis. Doctors who were unable to state any of the above entered "Don't know" on their answer sheets. An answer of "myocardial infarction" was accepted as correct for the three electrocardiograms showing acute transmural ischaemia (coved ST elevation) or typical acute myocardial infarct patterns with $Q$ waves.

Participating practitioners were asked not to discuss their diagnoses with colleagues and to complete a questionnaire about age, years in general practice, postgraduate training, and routine use of electrocardiography. The completed answer sheets and questionnaires were then sealed in unmarked envelopes to preserve anonymity. Doctors who were selected for inclusion in this survey but who did not attend the clinical meetings, were visited (without notice) in their health centres during surgery hours and invited to participate. Those agreeing were shown the six electrocardiograms and asked to complete the answer sheet and questionnaire, in the presence of one of the authors.

The $\chi^{2}$ test, with Yates' correction, and a significance level of $5 \%$ was used for statistical analysis. 
Table 3 Effect of six months of hospital training on ability of general practitioners to detect myocardial infarction (site not specified)

\begin{tabular}{llll}
\hline & $\begin{array}{l}\text { Training in medicine } \\
(n=51)\end{array}$ & \multicolumn{2}{l}{$\begin{array}{l}\text { No training in medicine } \\
(n=55)\end{array}$} \\
ECG diagnosis & $M I$ present $(\%)$ & $M I$ present $(\%)$ & $p$ \\
\hline $\begin{array}{l}\text { Acute inferior MI } \\
\text { Anteroseptal MI }\end{array}$ & $34(67)$ & $31(57)$ & NS \\
$\begin{array}{l}\text { Anterior MI with right bundle branch } \\
\text { block }\end{array}$ & $22(43)$ & $26(47)$ & NS \\
\hline
\end{tabular}

ECG, electrocardiogram; MI, myocardial infarction

Table 4 Effect of six months of hospital training on ability of general practitioners accurately to locate site of myocardial infarction (that is, offer correct diagnosis)

\begin{tabular}{|c|c|c|c|}
\hline ECG diagnosis & $\begin{array}{l}\text { Training in medicine } \\
(n=51)(\%)\end{array}$ & $\begin{array}{l}\text { No training in medicine } \\
(n=55)(\%)\end{array}$ & $p$ \\
\hline $\begin{array}{l}\text { Myocardial infarction: } \\
\text { Acute inferior } \\
\text { Anteroseptal } \\
\text { Anterior with right bundle branch }\end{array}$ & $\begin{array}{l}15(29) \\
14(27)\end{array}$ & $\begin{array}{l}17(31) \\
15(27)\end{array}$ & $\begin{array}{l}\text { NS } \\
\text { NS }\end{array}$ \\
\hline block & $5(10)$ & $4 \quad(7)$ & NS \\
\hline
\end{tabular}

ECG, electrocardiogram; MI, myocardial infarction.

Table 5 Effect of routine use of electrocardiography on ability of general practitioners to detect myocardial infarction (site not specified)

\begin{tabular}{llll}
\hline ECG diagnosis & $\begin{array}{l}\text { Routine use of ECG } \\
(n=31)\end{array}$ & $\begin{array}{l}\text { No routine use of ECG } \\
(n=75)\end{array}$ & $p$ \\
\hline $\begin{array}{l}\text { Acute inferior MI } \\
\text { Anteroseptal MI }\end{array}$ & $22(71 \%)$ & $43(57 \%)$ & NS \\
$\begin{array}{l}\text { Anterior MI with right bundle branch } \\
\text { block }\end{array}$ & $15(48 \%)$ & $33(44 \%)$ & NS \\
\hline
\end{tabular}

ECG, electrocardiogram; MI, myocardial infarction.

Table 6 Effect of routine use of electrocardiography on ability of general practitioners to offer correct diagnosis

\begin{tabular}{|c|c|c|c|}
\hline ECG diagnosis & $\begin{array}{l}\text { Routine use of ECG } \\
(n=31)(\%)\end{array}$ & $\begin{array}{l}\text { No routine use of } E C G \\
(n=75)(\%)\end{array}$ & $p$ \\
\hline Normal & $28(90)$ & $59(79)$ & NS \\
\hline $\begin{array}{l}\text { Myocardial infarction: } \\
\text { Acute inferior } \\
\text { Anteroseptal } \\
\text { Anterior with right bundle branch } \\
\text { block }\end{array}$ & $\begin{array}{r}12(39) \\
8(26) \\
2 \quad(6)\end{array}$ & $\begin{array}{ll}20 & (27) \\
21 & (28) \\
& \\
7 & (9)\end{array}$ & $\begin{array}{l}\text { NS } \\
\text { NS }\end{array}$ \\
\hline $\begin{array}{l}\text { Non-acute abnormality: } \\
\text { Left bundle branch block } \\
\text { Left ventricular hypertrophy and strain }\end{array}$ & $\begin{aligned} 10 & (32) \\
9 & (29)\end{aligned}$ & $\begin{array}{l}17(23) \\
14(19)\end{array}$ & $\begin{array}{l}\text { NS } \\
\text { NS }\end{array}$ \\
\hline
\end{tabular}

ECG, electrocardiogram.

Table 7 Effect of routine use of electrocardiography and six months of hospital training on ability of general practitioners to detect myocardial infarction (site not specified)

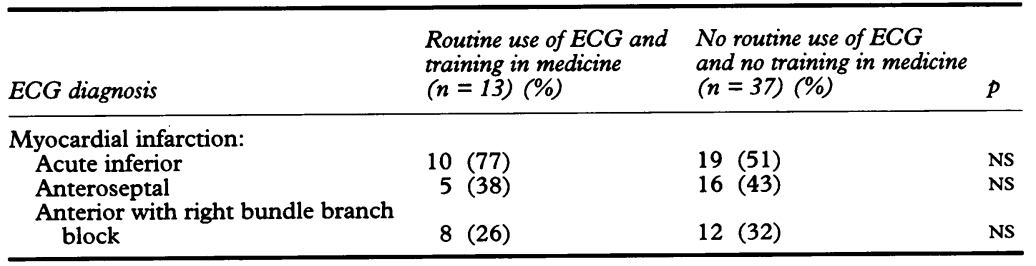

ECG, electrocardiogram; MI, myocardial infarction.

\section{Results}

One hundred and six of the 150 doctors selected for inclusion actually participated in this survey (52 attended one of the four clinical meetings and 54 were visited at their surgeries). Of the 44 doctors who did not take part in this study, 30 were unavailable at time of visit (on leave or on a domiciliary consultation), 10 refused, and four had retired or were dead. The mean age of participating doctors was 45 (range 28-74) and they had been general practitioners for a mean of 15 years (range 1-46). Fifty one $(48 \%)$ had had at least six months of postregistration hospital training in general medicine before their entry into general practice, but only $31(29 \%)$ claimed to carry routinely or to have immediate access to an electrocardiograph machine while on emergency calls.

Most doctors correctly classified an electrocardiogram as either normal $(82 \%)$ or abnormal (range 74-95\%) (table 1). When pressed to make a specific diagnosis (table 2), however, approximately half (range 34-59\%) the respondents did not recognise evidence of acute transmural ischaemia/infarction on an electrocardiogram. Between $33 \%$ and $61 \%$, depending on the specific trace presented, correctly identified such changes though only 8-30\% could accurately localise its site (table 2). Respondents were least able to identify anterior myocardial infarction in the presence of right bundle branch block. None of the respondents gave a completely correct answer, only $33 \%$ recognised an acute infarct pattern and only $8 \%$ localised it correctly (table 2).

Very few of the 106 doctors diagnosed myocardial infarction when it was not present, even when other electrocardiographic abnormalities were present (table 2). When shown an ECG demonstrating left bundle branch block, only four (4\%) doctors diagnosed infarction and only $10(9 \%)$ misinterpreted an ECG pattern of left ventricular hypertrophy and strain as showing changes typical of infarction (table 2). However, only $22 \%$ of respondents (for left ventricular hypertrophy and strain) and only $25 \%$ (for left bundle branch block) could correctly diagnose these non-acute abnormalities (table 2).

Six months of post-registration hospital training in general medicine neither significantly increased ability to recognise myocardial infarction on an electrocardiogram (table 3) nor conferred greater diagnostic skill in accurately locating the site of infarction compared with those doctors without such postgraduate experience (table 4). Similarly, doctors who claimed either routinely to carry, or to have immediate access to an electrocardiograph machine while on emergency calls (that is, routine ECG users) did not show greater expertise in identifying the presence of infarction on an electrocardiogram than their colleagues who did not (table 5).

Similarly, neither localisation of infarction nor the correct interpretation of non-acutely abnormal electrocardiograms was signifi- 
Table 8 Effect of routine use of electrocardiography and six months of hospital training on ability of general practitioners to offer correct diagnosis

\begin{tabular}{|c|c|c|c|}
\hline ECG diagnosis & $\begin{array}{l}\text { Routine use of ECG and } \\
\text { training in medicine } \\
(n=13)(\%)\end{array}$ & $\begin{array}{l}\text { No routine use of ECG } \\
\text { and no training in medicine } \\
(n=37)(\%)\end{array}$ & $p$ \\
\hline \multirow{3}{*}{$\begin{array}{l}\text { Normal } \\
\text { Myocardial infarction: } \\
\text { Acute inferior } \\
\text { Anteroseptal } \\
\text { Anterior with right bundle branch } \\
\text { block }\end{array}$} & $11(85)$ & $31(84)$ & NS \\
\hline & $\begin{array}{ll}5 & (38) \\
3 & (23)\end{array}$ & $\begin{array}{l}10(27) \\
10(27)\end{array}$ & $\begin{array}{l}\text { NS } \\
\text { NS }\end{array}$ \\
\hline & $1 \quad(7)$ & $3(8)$ & NS \\
\hline \multirow{2}{*}{$\begin{array}{l}\text { Non-acute abnormality: } \\
\text { Left bundle branch block } \\
\text { Left ventricular hypertrophy and } \\
\text { strain }\end{array}$} & $6(46)$ & $8(22)$ & NS \\
\hline & $4(31)$ & (8) & NS \\
\hline
\end{tabular}

ECG, electrocardiogram. expect that those who participated were likely to be more proficient and/or interested than those who did not. So the observed results were probably an over rather than under estimate of the electrocardiograph interpretation skills of the sample.

In addition, participating doctors were not alerted beforehand that their ability to interpret electrocardiograph tracings was to be assessed and neither discussion nor group conferring was possible because of close scrutiny by the authors. This contrasts with previous studies of electrocardiogram interpretation in general practice that were performed without invigilation and which, by their nature, involved doctors who were not truly representative of the general practitioner population. Such factors may well account for the higher level of diagnostic expertise reported. ${ }^{11} 12$

We consider that our results accurately reflect the current, average level of general practitioners' expertise in electrocardiogram interpretation within the Merseyside area and are thus applicable to the acute clinical situation outside hospital.

Interpretation of electrocardiograms is not a skill that general practitioners are required to use regularly, nor is it usually taught formally at post-graduate meetings so the levels of skill that we found are expected and predictable.

A British Heart Foundation Working Group report on the role of general practitioners in the management of patients with myocardial infarction recommended that only those proficient in interpretation of electrocardiograms should administer thrombolytic treatment. ${ }^{8}$ The results of our study suggest that, at present, this would exclude most family doctors. Furthermore, the working group recommended that electrocardiographic evidence of infarction should be sought by general practitioners before they decided whether thrombolysis was needed. ${ }^{8}$ However, our data indicate that many patients with suspected acute myocardial infarction who present with chest pain and a corroborative electrocardiogram might remain unrecognised. This means that thrombolysis in the community or after prompt referral to hospital will be delayed if its initiation depends on the recognition of electrocardiographic changes of infarction.

The British Heart Foundation Working Group also recommended that educational programmes in electrocardiogram interpretation should be available to general practitioners. ${ }^{8}$ It is worrying that we showed that neither shortlived hospital training in general medicine nor routine (though probably infrequent) use of electrocardiography conferred any greater ability to detect myocardial infarction on an electrocardiogram. Therefore, it is questionable whether the simple provision of a circumscribed course in electrocardiogram interpretation will produce any long-term improvement in the level of expertise among general practitioners. To achieve this would probably require prolonged tuition who did not attend the clinical meetings were subsequently approached individually in their surgeries. Approximately $70 \%$ of the sample (106 out of 150) eventually participated. We 
repeated at frequent intervals to maintain adequate standards.

Our results indicate that at least half of the general practitioners in the Merseyside area require such tuition, which would be expensive and time consuming. Similar educational exercises are likely to be needed throughout the United Kingdom.

If proficiency at interpretation of an electrocardiogram by general practitioners is a prerequisite for thrombolytic administration outside hospital, then either expensive, continuing educational programmes will need to be initiated or for the foreseeable future patients with acute myocardial infarction will continue to be denied the proven benefits of thrombolysis.

We thank Dr M C Colquhoun for his permission to reproduce the electrocardiogram dial infarction in the presence of right bundle branch block (fig 4).

1 GISSI-Effectiveness of intravenous thrombolytic treatment in acute myocardial infarction. Lancet 1986;i: $397-402$.

2 ISIS-2 (Second International Study of Infarct Survival) Collaborative Group. Randomised trial of intravenous streptokinase, oral aspirin, both, or neither among
17,187 cases of suspected acute myocardial infarction ISIS-2. Lancet 1988;ii:349-60.

3 AIMS Trial Study Group. Effect of intravenous APSAC on mortality after acute myocardial infarction: preliminary report of a placebo-controlled clinical trial. Lancet 1988;i:545-9.

4 McNeill A, Cunningham S, Flannery D, Dalzell G Wilson C, Tsoi E, et al. Pre-admission recombinan tissue plasminogen activator (abstr). Eur Heart $\mathcal{f} 1988 ; 9$ (suppl I):214.

5 Koren G, Weiss AT, Hasin Y, Appelbaum D, Welber S, Rozenman Y, et al. Prevention of myocardial damage in acute myocardial ischaemia by early treatment with intravenous streptokinase $N$ Engl f Med 1985.313 1384-9.

6 Van de Werf F, Arnold AER, for the European Study Group for recombinant tissue type plasminogen activa-

7 Rawles JM, Haites NE. Patient and general practitioner delays in acute myocardial infarction. $B M \mathcal{F}^{\prime} 1988 ; 296$ : 882-4.

8 Report of a British Heart Foundation Working Group Role of the general practitioner in managing patients with myocardial infarction: impact of thrombolytic treatment. BMf 1989;299:555-7.

9 Wilcox RG, Olsson CG, Skene AM, von der Lippe G, Jensen G, Hampton JR. Trial of tissue plasminogen activator for mortality reduction in acute myocardial infarction. Anglo-Scandinavian study of early thrombolysis (ASSET). Lancet 1988;ii:525-30.

10 Colquhoun MC. General practitioners' use of electrocardiography: relevance to early thrombolytic treatment. cardiography: relevance

11 Macallan DC, Bell JA, Braddick $M$, Endersby $K$, Rizzo-Naudi J. The electrocardiogram in general practice: its use and its interpretation. $f R$ Soc Med 1990

12 Rawles JM. General practitioners' management of acute myocardial infarction and cardiac arrest: relevance to thrombolytic treatment. $B M \mathcal{F} 1987 ; 295: 639-40$. 